Scientific paper

\title{
Synthesis, Structure and Electrochemistry of Tetranuclear Oxygen-Centered Copper(II) Clusters with Acetylacetone and Benz-pyrazole Hydrolyzed Derivatives as Ligand
}

\author{
Rasoul Vafazadeh ${ }^{1, *}$ and Anthony C. Willis ${ }^{2}$ \\ ${ }^{1}$ Department of Chemistry, Yazd University, Yazd, Iran. \\ ${ }^{2}$ Research School of Chemistry, Australian National University, Canberra, ACT 2601, Australia. \\ *Corresponding author: E-mail: rvafazadeh@yazd.ac.ir and rvafazadeh@gmail.com \\ Tel: +983538214778 Fax: +983537250110
}

Received: 19-01-2016

\begin{abstract}
Two copper(II) clusters $\mathrm{Cu}_{4} \mathrm{OCl}_{6}$ (pyrazole) $)_{4}(\mathbf{1})$ and $\mathrm{Cu}_{4} \mathrm{OBr}_{6}(\mathrm{Br} \text {-pyrazole })_{4}(\mathbf{2})$ have been synthesized by reacting acetylacetone and benzohydrazide (1:1 ratio) with $\mathrm{CuX}_{2}(\mathrm{X}=\mathrm{Cl}$ for 1 and $\mathrm{X}=\mathrm{Br}$ for 2$)$ in methanol solution. The structures of both clusters have been established by $\mathrm{X}$-ray crystallography. The clusters contain four $\mathrm{Cu}$, one $\mathrm{O}$, six $\mu_{2}-\mathrm{X}$ atoms, and four pyrazole ligands. The pyrazole was prepared in situ by the reaction of acetylacetone with benzohydrazide in methanol under reflux. In $\mathbf{2}$, the methine hydrogen of the pyrazole ligand has been replaced by bromine atom. The four copper atoms encapsulate the central $\mathrm{O}$ atom in a tetrahedral arrangement. All copper atoms are five-coordinate and have similar coordination environments with slightly distorted trigonal bipyramidal geometry. The cyclic voltammogram of the clusters 1 and 2 show a one-electron quasi-reversible reduction wave in the region 0.485 to $0.731 \mathrm{~V}$, and a one-electron quasi-reversible oxidation wave in the region 0.767 to $0.898 \mathrm{~V}$. In $\mathbf{1}$, one irreversible oxidative response is observed on the positive of side of the voltammogram at $1.512 \mathrm{~V}$ and this can be assigned to $\mathrm{Cu}$ (II) to $\mathrm{Cu}$ (III) oxidation.
\end{abstract}

Keywords: Copper clusters; Pyrazole; Crystal structures; Cyclic voltammetry; Tetranuclear

\section{Introduction}

The synthesis of multi-metal clusters by spontaneous self-assembly of organic-inorganic ligands and transitionmetal ions have attracted special attention due to their potential application in magnetic, electrochemical, catalytic studies and coordination chemistry. ${ }^{1-9}$ A feature of modern coordination chemistry is its development of metal bio-sites modeling for biology systems. ${ }^{10}$ Self-assembly is one of the few practical strategies for making such compounds. The spontaneous self-assembly of well-defined and complex molecular entities from constituent subunits occurs in solution. ${ }^{11}$ In biology systems, self-assembly occurs by weak inter- or intra-molecular interactions of non-covalent bonds, while self-assembly in coordination chemistry occurs through the formation of covalent coordinate bonds. ${ }^{11-15}$
It is well known that the constituent ligands and metals play important roles in the structures and properties of the multi-metal clusters. The synthesis and characterization of high nuclearity metal clusters with oxo bridges has been the goal of much research. ${ }^{15-20}$ Oxo-copper(II) halide clusters have been extensively studied. ${ }^{20-23}$ Bertrand reported the first structure in $1966 .{ }^{24}$ The usual arrangement in tetranuclear $\mathrm{Cu}_{4} \mathrm{OX}_{6} \mathrm{~L}_{4}$ complexes consists of a central oxygen atom bound to four tetrahedrally arranged copper(II) atoms. At the same time, each copper(II) atom adopts a trigonal bipyramidal coordination with one terminal axial position occupied by ligand L. Many novel complexes or coordination polymers based on ligands generated in situ have been synthesized through one-pot reaction under hydrothermal or solution reaction conditions. ${ }^{25-27}$ Here we report the synthesis, characterization 
and electrochemistry of tetranuclear copper(II) clusters $\mathbf{1}$ and 2 , obtained by reaction of $\mathrm{CuX}_{2}(\mathrm{X}=\mathrm{Cl}$ and $\mathrm{Br})$ and pyrazole ligands generated in situ under hydrothermal conditions.

\section{Experimental}

\section{1. Reagents and Physical Measurements}

All chemicals were used as supplied by Merck and Fluka without further purification. Infrared spectra were taken with an Equinox 55 Bruker FT-IR spectrometer using $\mathrm{KBr}$ pellets in the $400-4000 \mathrm{~cm}^{-1}$ range. Absorption spectra were determined in the solvent methanol using a GBC UV-Visible Cintra 101 spectrophotometer with $1 \mathrm{~cm}$ quartz, in the range of $200-800 \mathrm{~nm}$ at $25{ }^{\circ} \mathrm{C}$. Elemental analyses $(\mathrm{C}, \mathrm{H}, \mathrm{N})$ were performed using a CHNS-O 2400II PERKIN-ELMER elemental analyzer. Cyclic voltammetry was carried out using an Autolab potentiostate/galvanostate (PGSTAT-302N) instrument. The measurements were performed at $300 \mathrm{~K}$ in acetonitrile solutions containing $0.1 \mathrm{M}$ tetrabutylammonium perchlorate (TBAP) and $0.1 \mathrm{mM}$ copper(II) complexes deoxygenated by bubbling with nitrogen. The working, counter, and reference electrodes used were glassy carbon electrode, platinum wire and $\mathrm{Ag} / \mathrm{AgCl}(3.0 \mathrm{KCl})$, respectively.

\section{2. X-ray Crystallography}

Diffraction images were measured at $200 \mathrm{~K}$ on a Nonius Kappa CCD diffractometer using Mo $K \alpha$, graphite monochromator $(\lambda=0.71073 \AA)$. Data were extracted using the DENZO/SCALEPACK package. ${ }^{28}$ Structures were solved by direct methods with the use of SIR92 and refined

Table 1. Crystallographic data of complex 2

\begin{tabular}{ll}
\hline Compound & $\mathbf{2}$ \\
\hline Chemical formula & $\mathrm{C}_{20} \mathrm{H}_{28} \mathrm{Br}_{10} \mathrm{Cu}_{4} \mathrm{~N}_{8} \mathrm{O}$ \\
Formula weight & 1449.72 \\
Temperature $(K)$ & 200 \\
Space group & Tetragonal, I $_{1} / a$ \\
$Z$ & 4 \\
$a(\AA)$ & $17.3344(3)$ \\
$b(\AA)$ & $17.3344(3)$ \\
$c(\AA)$ & $12.7924(2)$ \\
$\alpha\left({ }^{\circ}\right)$ & 90 \\
$\beta\left(^{\circ}\right)$ & 90 \\
$\gamma\left({ }^{\circ}\right)$ & 90 \\
$V\left(\AA^{3}\right)$ & $3843.88(11)$ \\
$F(000)$ & 2712 \\
$D_{c a l c}\left(\mathrm{~g} \mathrm{~cm}^{-3}\right)$ & 2.505 \\
$\propto\left(\mathrm{mm}^{-1}\right)$ & 12.61 \\
$R\left[F^{2}>2 \sigma\left(F^{2}\right)\right]$ & 0.035 \\
$w R\left(F^{2}\right)($ all data $)$ & $0.087^{*}$ \\
\hline
\end{tabular}

${ }^{*} w=1 /\left[\sigma^{2}\left(F^{2}\right)+(0.04 \mathrm{P})^{2}+20.94 \mathrm{P}\right]$, where $\mathrm{P}=\left(\max \left(F_{o}{ }^{2}, 0\right)+2 F_{c}{ }^{2}\right) / 3$ on $F^{2}$ by full matrix last-squares techniques using the CRYSTALS program package. ${ }^{29,30}$ Atomic coordinates, bond lengths and angles, and displacement parameters were deposited at the Cambridge Crystallographic Data Centre. Crystallographic details are summarized in Table 1.

\section{3. Syntheses of Tetranuclear Copper(II) Clusters}

The cluster 1 was prepared as previously reported. ${ }^{26}$ The cluster $\mathbf{2}$ was synthesized similar to cluster 1, acetylacetone $(1.05 \mathrm{~mL}, 10 \mathrm{mmol})$ was added to a methanol solution $(25 \mathrm{~mL})$ of benzohydrazide $(1.36 \mathrm{~g}, 10 \mathrm{mmol})$, and the mixture was heated to reflux for $5 \mathrm{~h}$. A solution of $\mathrm{Cu}-$ $\mathrm{Br}_{2}(2.23 \mathrm{~g}, 10 \mathrm{mmol})$ in methanol was added to the above-mentioned bright yellow solution. The green solution was stirred at room temperature for $2 \mathrm{~h}$.

Cluster 1: Yield 40\%. Anal. Calcd. for $\mathrm{C}_{20} \mathrm{H}_{32} \mathrm{Cl}_{6} \mathrm{Cu}_{4} \mathrm{~N}_{8} \mathrm{O}: \mathrm{C}, 27.69 ; \mathrm{H}, 3.72 ; \mathrm{N}, 12.92$. Found: $\mathrm{C}$, $27.57 ; \mathrm{H}, 4.01 ; \mathrm{N}, 12.52 \%$. IR $\left(\mathrm{KBr}, \mathrm{cm}^{-1}\right)$ : vC=N (pyrazol ring $)=1572, v \mathrm{~N}-\mathrm{H}=3335$. Electronic spectra in methanol: $\lambda_{\max }(\mathrm{nm}),(\log \varepsilon): 813$ (2.24), 311 (3.59).

Cluster 2: A green-brown precipitate was obtained upon the slow evaporation of the solvents at room temperature over two days. Dark-green block crystals were obtained by slow evaporation of the mother liquor and were washed with methanol and dried in air. Yield $25 \%$. Anal. Calcd. for $\mathrm{C}_{20} \mathrm{H}_{28} \mathrm{Br}_{10} \mathrm{Cu}_{4} \mathrm{~N}_{8} \mathrm{O}$ : C, 16.57; H, 1.95; N, 7.73. Found: C, 16.72; H, 2.01; N, 7.52\%. IR $\left(\mathrm{KBr}, \mathrm{cm}^{-1}\right)$ : $v \mathrm{C}=\mathrm{N}$ (pyrazol ring) $=1566, v \mathrm{~N}-\mathrm{H}=3310$. Electronic spectra in methanol: $\lambda_{\max }(\mathrm{nm}),(\log \varepsilon): 823$ (2.07), 316 (3.42).

\section{Result and Discussion}

\section{1. Synthesis}

The synthetic route of the clusters is shown in Scheme 1. Clusters $\mathbf{1}$ and $\mathbf{2}$ were synthesized by a two-stepsone-pot reaction with the initial formation of the pyrazole (without its isolation) and then the addition of a methanolic solution of $\mathrm{CuX}_{2}(\mathrm{X}=\mathrm{Cl}$ and $\mathrm{Br})$. The pyrazole was prepared in situ from the reactions between acetylacetone and benzohydrazide in methanol under reflux. Initially, (3,5-dimethyl-1H-pyrazol-1-yl)(phenyl)methanone (benz-pyrazole) was obtained by the reaction of equimolar amount of acetylacetone and benzohydrazide. ${ }^{31}$ The resulting solution was refluxed for $5 \mathrm{~h}$ and then was used for the synthesis of the complex without further purification.

Cluster $\mathbf{1}, \mathrm{Cu}_{4} \mathrm{Cl}_{6} \mathrm{O}$ (pyrazole) ${ }_{4}$, was obtained by the reaction between $\mathrm{CuCl}_{2}$ and benz-pyrazole in association with hydrolysis at room temperature (Scheme 1). A search of the literature revealed that the cluster had been reported previously by Jaćimović et al. in 2007. ${ }^{32}$ They synthesized the green crystals of the copper(II) cluster from the one- 


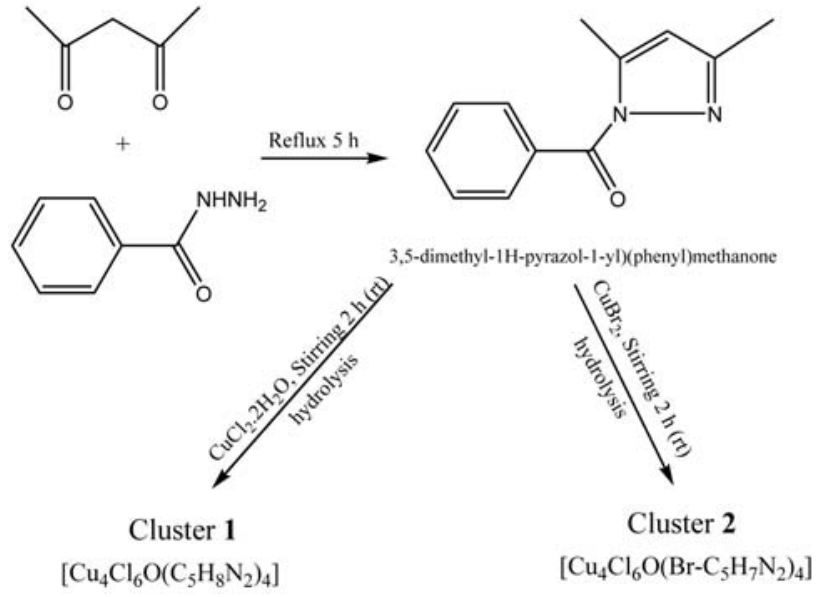

Scheme 1. Schematic illustration for the synthesis of $\mathrm{Cu}(\mathrm{II})$ clusters

pot reaction of 3,5-dimethylpyrazole-1-carboxamide and $\mathrm{CuCl}_{2}$ in hot ethanol solvent.

Reaction between a methanol solution containing benz-pyrazole and $\mathrm{CuBr}_{2}$ at room temperature leads to formation of cluster $2, \mathrm{Cu}_{4} \mathrm{Br}_{6} \mathrm{O}(\mathrm{Br} \text {-pyrazole) })_{4}$ (Scheme 1).

\section{2. Crystal Structures}

The structure of cluster $\mathbf{1}$ is similar to the structure that has been previously reported. ${ }^{32}$ In the Jaćimović report, the space group was triclinic $P \bar{l}$. This crystal structure contained a region of electron density external to the atoms of the complex molecule which suggested the presence of ethanol solvate molecules. Attempts to find a satisfactory structural model for these molecules however failed, and SQUEEZE was used to correct the data set for the electron density in this region of the cell. Our determination is in the monoclinic space group $P 2 / n$. It also contains disordered solvate species, though not ethanol. This same cell was reported to the Cambridge Structure Database as a private communication by Stibrany and Potenza in 2007. ${ }^{33}$ Crystallographic data for our determination of the structure of cluster 1 were given previously. ${ }^{26}$ Selected interatomic distances and angles for $\mathbf{1}$ are given in Table 2 to allow direct comparisons values for cluster 2 . Both structures were run at the same temperature (200 K).

The molecular structures of the clusters, with selected atoms labeled, are shown in Figures 1 and 2. Selected bond lengths and angles are given in Table 2. The clusters each contains four $\mathrm{Cu}$, one $\mu_{4-} \mathrm{O}$ and six $\mu_{2}-\mathrm{X}$ atoms $(\mathrm{X}=\mathrm{Cl}$ and $\mathrm{Br}$ ), along with four 3,5-dimethyl- $1 H$-pyrazole ligands for 1 and four 4-bromo-3,5-dimethyl-1 $H$-pyrazole ligands for 2 . The four $\mathrm{Cu}(\mathrm{II})$ ions form a nearly ideal tetrahedral skeletal structure with the $\mathrm{Cu} \cdots \mathrm{Cu} \cdots \mathrm{Cu}$ angles ranging from 59.0 to $61.3^{\circ}$ (for $\mathbf{1}$ ) and 59.6 to $61.2^{\circ}$ (for 2) and $\mathrm{Cu} \cdots \mathrm{Cu}$ distances ranging from 3.078-3.203 and 3.127-3.145 $\AA$, for $\mathbf{1}$ and $\mathbf{2}$ respectively, which are comparable with those found in similar cluster compounds. ${ }^{15,34-37}$ The four copper
Table 2. Selected bond lengths $(\AA)$ and angles $\left(^{\circ}\right)$ in complexes 1 and $2^{\mathrm{a}}$

\begin{tabular}{|c|c|c|c|}
\hline \multicolumn{2}{|l|}{ Complex 1} & \multicolumn{2}{|l|}{ Complex 2} \\
\hline$\overline{\mathrm{Cu} 1-\mathrm{Cl} 1}$ & $2.3580(11)$ & $\mathrm{Cu} 1-\mathrm{Br} 1$ & $2.5072(6)$ \\
\hline $\mathrm{Cu} 1-\mathrm{Cl} 4$ & 2.4386 (19) & $\mathrm{Cu} 1-\mathrm{Br} 2$ & $2.5163(6)$ \\
\hline $\mathrm{Cu} 1-\mathrm{Cl} 2^{\mathrm{i}}$ & $2.4069(12)$ & $\mathrm{Cu} 11^{\mathrm{i}}-\mathrm{Br} 1$ & $2.5807(6)$ \\
\hline $\mathrm{Cu} 1-\mathrm{N} 1$ & $1.9620(3)$ & $\mathrm{Cu} 1^{\mathrm{ii}}-\mathrm{Br} 2$ & $2.5163(6)$ \\
\hline $\mathrm{Cu} 1-\mathrm{O} 1$ & $1.9072(17)$ & $\mathrm{Cu} 1-\mathrm{Cu} 1^{\mathrm{i}}$ & $3.1450(7)$ \\
\hline $\mathrm{Cu} 2-\mathrm{Cl1}$ & $2.3567(10)$ & $\mathrm{Cu} 1-\mathrm{Cu} 1^{\mathrm{ii}}$ & $3.1274(8)$ \\
\hline $\mathrm{Cu} 2-\mathrm{Cl} 2$ & $2.3810(10)$ & $\mathrm{Cu} 1-\mathrm{O} 1$ & $1.9223(4)$ \\
\hline $\mathrm{Cu} 2-\mathrm{Cl} 3$ & $2.4901(11)$ & $\mathrm{Cu} 1-\mathrm{N} 1$ & $1.967(3)$ \\
\hline $\mathrm{Cu} 2-\mathrm{N} 3$ & $1.9530(3)$ & $\mathrm{N} 1-\mathrm{N} 2$ & $1.355(4)$ \\
\hline $\mathrm{Cu} 2-\mathrm{O} 1$ & $1.9091(16)$ & $\mathrm{N} 1-\mathrm{C} 4$ & $1.342(4)$ \\
\hline N1-N2 & $1.3550(4)$ & $\mathrm{C} 3-\mathrm{Br} 3$ & $1.871(3)$ \\
\hline $\mathrm{N} 1-\mathrm{C} 4$ & $1.3340(4)$ & $\mathrm{C} 2-\mathrm{N} 2$ & $1.343(5)$ \\
\hline $\mathrm{Cl} 1-\mathrm{Cu} 1-\mathrm{Cl} 2^{\mathrm{i}}$ & $116.83(5)$ & $\mathrm{Br} 1{ }^{\mathrm{iii}}-\mathrm{Cu} 1-\mathrm{Br} 2$ & $108.83(2)$ \\
\hline $\mathrm{Cl1}-\mathrm{Cu} 1-\mathrm{O} 1$ & $85.46(4)$ & $\mathrm{Br}{ }^{\mathrm{iii}}-\mathrm{Cu} 1-\mathrm{Br} 1$ & $118.90(2)$ \\
\hline $\mathrm{Cl} 4-\mathrm{Cu} 1-\mathrm{O} 1$ & $82.59(8)$ & $\mathrm{Br} 2-\mathrm{Cu} 1-\mathrm{Br} 1$ & $131.17(2)$ \\
\hline $\mathrm{Cl1}-\mathrm{Cu} 1-\mathrm{N} 1$ & $96.12(9)$ & $\mathrm{Br} 2-\mathrm{Cu} 1-\mathrm{O} 1$ & 87.145 (17) \\
\hline $\mathrm{Cl} 4-\mathrm{Cu} 1-\mathrm{N} 1$ & 92.75 (10) & $\mathrm{Br} 2-\mathrm{Cu} 1-\mathrm{N} 1$ & $92.85(9)$ \\
\hline $\mathrm{O} 1-\mathrm{Cu} 1-\mathrm{N} 1$ & $174.33(11)$ & $\mathrm{Br} 1-\mathrm{Cu} 1-\mathrm{O} 1$ & 87.189 (18) \\
\hline $\mathrm{Cl} 1-\mathrm{Cu} 2-\mathrm{Cl} 2$ & $125.74(5)$ & $\mathrm{Br} 1-\mathrm{Cu} 1-\mathrm{N} 1$ & $93.14(8)$ \\
\hline $\mathrm{Cl} 1-\mathrm{Cu} 2-\mathrm{Cl} 3$ & $117.96(4)$ & $\mathrm{O} 1-\mathrm{Cu} 1-\mathrm{N} 1$ & $179.56(9)$ \\
\hline $\mathrm{O} 1-\mathrm{Cu} 2-\mathrm{N} 3$ & $175.97(5)$ & $\mathrm{Cu} 1^{\mathrm{i}}-\mathrm{O} 1-\mathrm{Cu} 1$ & $109.774(12)$ \\
\hline $\mathrm{Cu} 1-\mathrm{O} 1-\mathrm{Cu} 2$ & $107.53(17)$ & $\mathrm{Cu} 1-\mathrm{O} 1-\mathrm{Cu} 1^{\mathrm{ii}}$ & $108.87(2)$ \\
\hline $\mathrm{Cu} 1-\mathrm{O} 1-\mathrm{Cu} 1^{\mathrm{i}}$ & $111.06(15)$ & $\mathrm{Cu} 1^{\mathrm{i}}-\mathrm{Br} 1-\mathrm{Cu} 1$ & $76.34(2)$ \\
\hline $\mathrm{Cu} 1-\mathrm{O} 1-\mathrm{Cu} 2^{\mathrm{i}}$ & $108.36(18)$ & & \\
\hline
\end{tabular}

a symmetry codes for 1 : (i) $-x+3 / 2, y,-z+3 / 2$ and for 2 : (i) $y+$ $1 / 4,-x+3 / 4,-z+7 / 4$; (ii) $-x+1,-y+1 / 2, z$; (iii) $-y+3 / 4, x-$ $1 / 4,-z+7 / 4$.

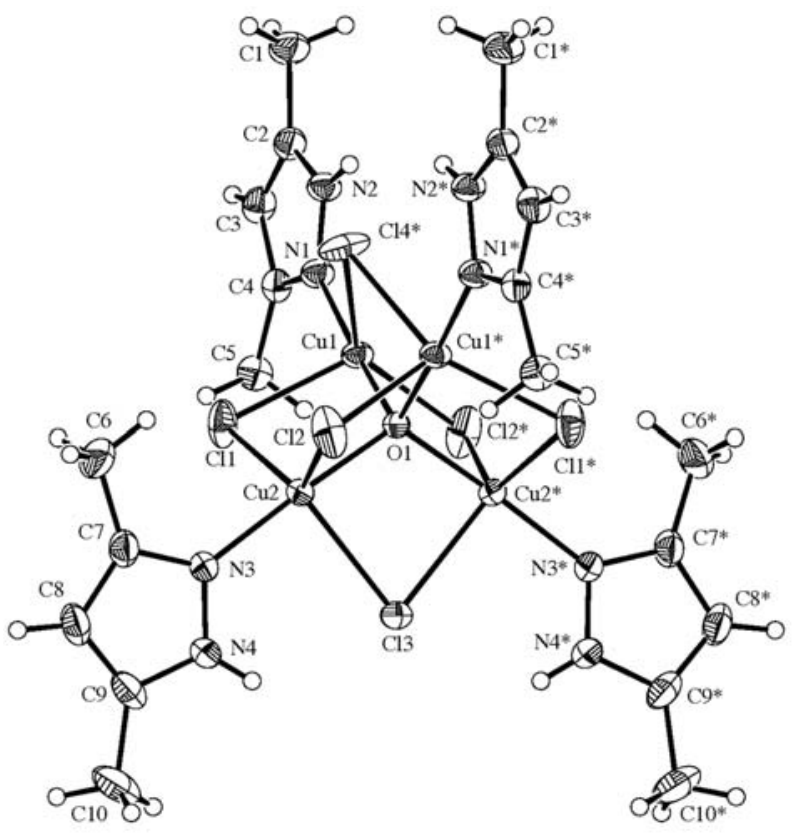

Figure 1. The structure of the $\left[\mathrm{Cu}_{4} \mathrm{Cl}_{6} \mathrm{O}\left(\mathrm{C}_{5} \mathrm{H}_{8} \mathrm{~N}_{2}\right)_{4}\right]$ molecule, cluster 1, with labelling of selected atoms, showing only one location of the disordered atom $(\mathrm{Cl} 4)$. Asterisks indicate atoms generated by symmetry operations. Anisotropic displacement ellipsoids exhibit $30 \%$ probability levels. Hydrogen atoms are drawn as circles with small radii 


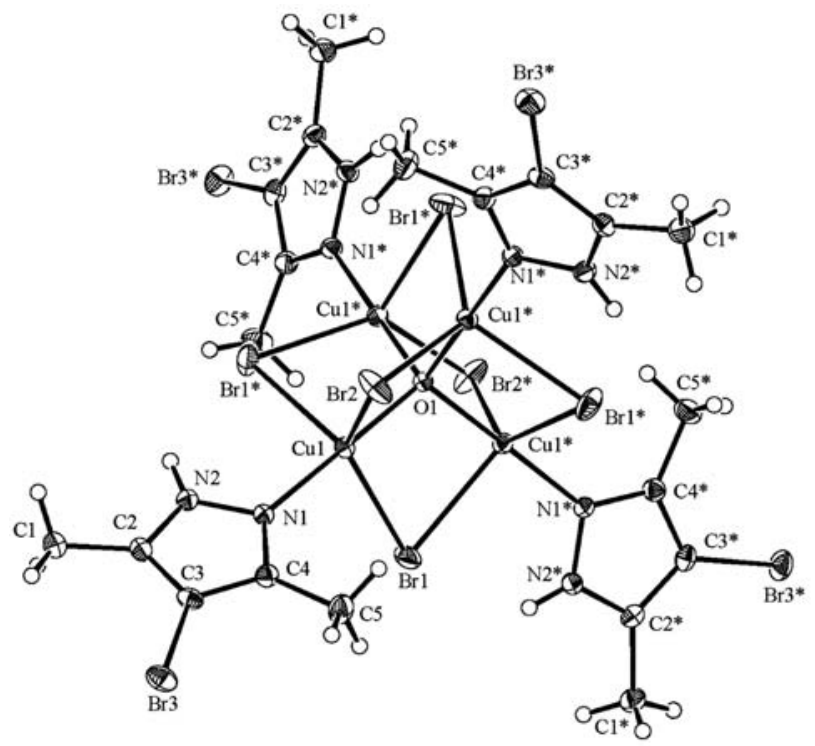

Figure 2. The structure of the $\left[\mathrm{Cu}_{4} \mathrm{Br}_{6} \mathrm{O}\left(\mathrm{C}_{5} \mathrm{H}_{7} \mathrm{~N}_{2} \mathrm{Br}\right)_{4}\right]$ molecule, cluster 2, with labelling of selected atoms. Asterisks indicate atoms generated by symmetry operations. Anisotropic displacement ellipsoids exhibit $30 \%$ probability levels. Hydrogen atoms are drawn as circles with small radii

atoms encapsulate a central $\mathrm{O}$ atom in a distorted tetrahedral arrangement (Figure 3). The $\mathrm{Cu}-\mathrm{O}$ bond lengths are 1.907(2) and 1.909(2) $\AA$ for $\mathbf{1}$ and 1.9223(4) $\AA$ for $\mathbf{2}$. The $\mathrm{Cu}-\mathrm{O}-\mathrm{Cu}$ angles in $\mathbf{1}$ and $\mathbf{2}$ are 107.53(2)-114.04(2) ${ }^{\circ}$ and 108.87(2)-109.77(1), respectively; these result are in agreement with $109.47^{\circ}$ for an ideal tetrahedron. Between each pair of copper atoms there is a bridging chlorine atom with $\mathrm{Cu}-\mathrm{Cl}$ distances of 2.3567(10)-2.4908(2) $\AA$ for $\mathbf{1}$, and a bridging bromine atom with $\mathrm{Cu}-\mathrm{Br}$ distances of 2.5072(6)-2.5807(6) $\AA$ for $\mathbf{2}$. In 2, the methine hydrogen of the pyrazole ligand has been replaced by a bromine atom with a C-Br distance of 1.871(3) ̊.

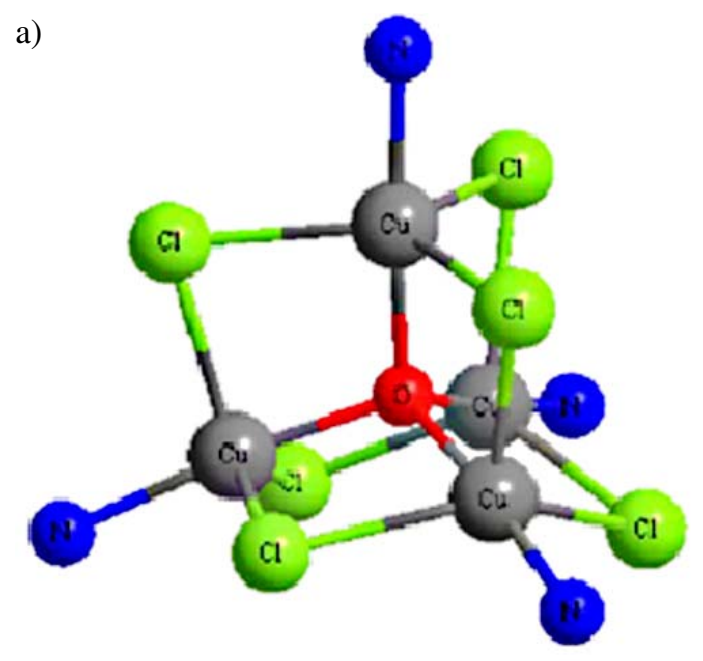

The four copper atoms are five-coordinate and have similar coordination environments (Fig. 3). The geometry of the copper atoms in $\mathbf{1}$ and $\mathbf{2}$ are best described as having a distorted trigonal bipyrmid coordination sphere with structural parameter $\tau \approx 0.90$ for $\mathbf{1}$ and $\tau \approx 0.80$ for $\mathbf{2}$. The parameter $\tau$ is defined as $\tau=(\alpha-\beta) / 60, \alpha>\beta$, where $\alpha$ and $\beta$ are the largest angles, so $\tau=1$ for a regular trigonal bipyrmid and $\tau=0$ for a regular square pyramid. ${ }^{38}$ The three halogen atoms lie in the equatorial positions of the trigonal bipyramid, while the central oxygen and the pyridine nitrogen from the pyrazole ligand are placed at the axial sites. The $\mathrm{O}-\mathrm{Cu}-\mathrm{Cl}$ and $\mathrm{N}-\mathrm{Cu}-\mathrm{Cl}$ bond angles in $\mathbf{1}$ are 81.18(8)-85.74(4) ${ }^{\circ}$, and 92.75(10)-99.03(9) ${ }^{\circ}$, respectively. The $\mathrm{O}-\mathrm{Cu}-\mathrm{Br}$ and $\mathrm{N}-\mathrm{Cu}-\mathrm{Br}$ bond angles in 2 are 85.106(17)-87.189(18) ${ }^{\circ}$, and 92.85(9)-94.48(8) ${ }^{\circ}$, respectively.

In cluster 1 , the planes of the pyrazole rings are angled about 78 to each other, while in $\mathbf{2}$ the angles are about 57 .

\section{3. Cyclic Voltammetry}

The electrochemical behavior of the $\mathrm{Cu}$ (II) complexes has been studied by cyclic voltammetry (CV) in $\mathrm{CH}_{3} \mathrm{CN}$ solution. Tetrabutylammonium perchlorate (TBAP, $0.1 \mathrm{M}$ ) was used as the supporting electrolyte. The electrochemical data are summarized in Table 3 and the cyclic voltammograms of the copper(II) complexes are depicted in Fig. 4. As shown in figure 4a, cluster 1 shows a pair of redox peaks with a cathodic peak potential $\left(E_{\mathrm{pc}}\right)$ at $0.485 \mathrm{~V}$ and an anodic peak potential $\left(E_{\mathrm{pa}}\right)$ at $0.767 \mathrm{~V}$. The half-wave potential $\left(E_{1 / 2}=1 / 2\left(E_{\mathrm{pa}}+E_{\mathrm{pc}}\right)\right)$ and the peak-to-peak potential separation $\left(\Delta E_{\mathrm{p}}\right)$ were obtained as $0.626 \mathrm{~V}$ and $0.282 \mathrm{~V}$, respectively, indicating that the electrochemical behavior of $\mathbf{1}$ is quasi-reversible corresponding to the redox process of all four copper $(\mathrm{Cu}(\mathrm{II}) / \mathrm{Cu}(\mathrm{I})){ }^{39-41}$ The crystal structures of complex $\mathbf{1}$

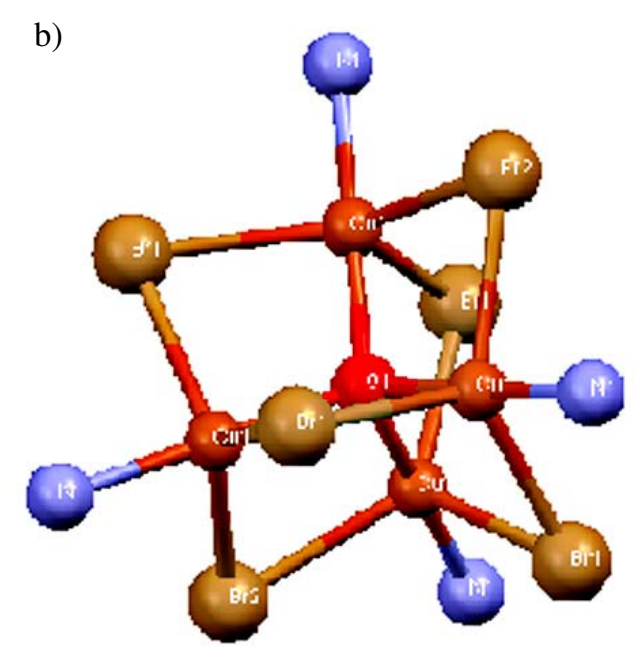

Figure. 3. Cluster core (a) cluster $\mathbf{1}$ and (b) cluster $\mathbf{2}$ 
shows the presence of four similar $\mathrm{Cu}$ (II) centers in the tetranuclear cluster, so we can assume that in solution the four copper ions exhibit similar coordination environments as in the solid state. One irreversible oxidative response is observed on the positive of side of voltammogram at $1.512 \mathrm{~V}$ and this can be assigned to $\mathrm{Cu}$ (II) to $\mathrm{Cu}$ (III) oxidation.

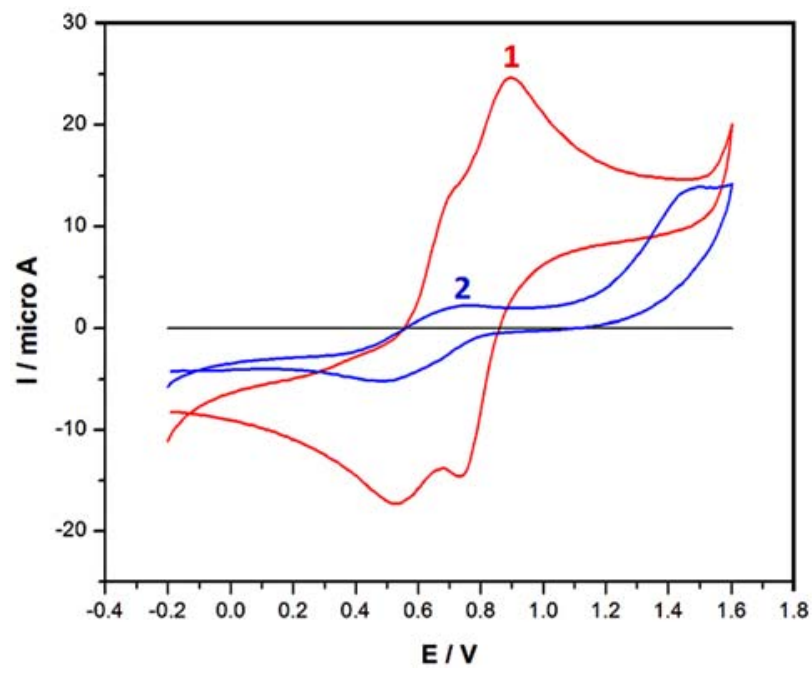

Figure 4. Cyclic voltammograms of the complexes $\mathbf{1}$ and $\mathbf{2}$ in a 0.1 $\mathrm{M}$ TBAP acetonitrile solution at $300 \mathrm{~K}$ and $100 \mathrm{mV} / \mathrm{s}$.

The cyclic voltammogram for copper(II) complex 2 was recorded at anodic potential in the range -0.2 to +1.6 $\mathrm{V}$. The cyclic voltammogram for 2 is shown in Fig. 4b. On changing the halogen from $\mathrm{Cl}$ to $\mathrm{Br}$ more redox peaks are observed. This usually happens when $\mathrm{Cl}$ is changed to $\mathrm{Br}$ or I in similar core structures. ${ }^{42-44}$ The cyclic voltammetry of 2 shows two anodic peaks potential at 0.716 and 0.898 $\mathrm{V}$ and two cathodic peaks at 0.731 and $0.530 \mathrm{~V}$. We could not get any wave for the oxidation of copper(II) to copper(III) in the potential range up to $1.6 \mathrm{~V}$.

Table 3. Cyclic voltammetric data for complexes $\mathbf{1}$ and $\mathbf{2}$ (versus $\mathrm{Ag} / \mathrm{AgCl})$

\begin{tabular}{cccc}
\hline complex & $\boldsymbol{E}_{\mathbf{p c}}(\mathbf{V})$ & $\boldsymbol{E}_{\mathbf{p a}}(\mathbf{V})$ & $\boldsymbol{E}_{\mathbf{1 / 2}}(\mathbf{m V})$ \\
\hline 1 & 0.485 & $0.767,1.512$ & 0.626 \\
2 & $0.530,0.731$ & $0.716,0.898$ & $0.623,0.815$ \\
\hline
\end{tabular}

\section{Conclusion}

The present work describes the synthesis by a twosteps-one-pot reaction, characterization, and electrochemical behavior of copper(II) clusters 1 and 2. Single crystal X-ray diffraction studies revealed that the two com- plexes have similar structures, namely a tetranuclear cluster containing four $\mathrm{Cu}$, one $\mu_{4}-\mathrm{O}$, six $\mu_{2}-\mathrm{X}$ atoms $(\mathrm{X}=\mathrm{Cl}$, $\mathbf{1}$ and $\mathrm{Br}, \mathbf{2})$, and four pyrazole ligands. The electrochemical behavior of clusters $\mathbf{1}$ and $\mathbf{2}$ are quasi-reversible corresponding to the redox process of all four copper $(\mathrm{Cu}(\mathrm{II}) / \mathrm{Cu}(\mathrm{I}))$.

\section{Supplementary Material}

The deposition number of the studied cluster $\mathbf{2}$ is CCDC 1404320. These data can be obtained free-of-charge via www.ccdc.cam.ac.uk/data_request/cif, by emailing data-request@ccdc.cam.ac.uk, or by contacting The Cambridge Crystallographic Data Centre, 12 Union Road, Cambridge CB2 1EZ, UK; fax +44 1223336033.

\section{Acknowledgments}

The authors are grateful to the Yazd University and the Australian National University for partial support of this work.

\section{References}

1. J.-M. Lehn, Supramolecular Chemistry: Concepts and Perspectives, VCH, Weinheim, 1995.

http://dx.doi.org/10.1002/3527607439

2. P. Halder, P. R. Banerjee, E. Zangrando, T. K. Paine, Eur. J. Inorg. Chem., 2008, 5659-5665. http://dx.doi.org/10.1002/ejic.200800817

3. A. B. Descalzo, R. Martinez-Manez, F. Sancenon, K. Hoffmann, K. Rurack, Angew. Chem., Int. Ed., 2006, 45, 59245948. http://dx.doi.org/10.1002/anie.200600734

4. R. Vafazadeh, Z. Moghadas, A. C. Willis, J. Coord. Chem. 2015, 68, 4255-4271.

http://dx.doi.org/10.1080/00958972.2015.1096349

5. B. Dojer, A. Pevec, F. Belaj, M. Kristl, Acta Chim. Slov. 2015, 62, 312-318.

http://dx.doi.org/10.17344/acsi.2014.1111

6. R. Vafazadeh, B. Khaledi, A. C. Willis, M. Namazian, Polyhedron, 2011, 30, 1815-1819.

http://dx.doi.org/10.1016/j.poly.2011.04.026

7. R. Vafazadeh, B. Khaledi, A. C. Willis, Acta Chim. Slov. 2012, 59, 954-958.

8. M. Kasunič, K. Gačnik, P. Šegedin, A. Golobič, Acta Chim. Slov. 2010, 57, 350-354.

9. R. Vafazadeh, A. C. Willis, J. Coord. Chem. 2015, 68, 22402252.

http://dx.doi.org/10.1080/00958972.2015.1048688

10. E. I. Solomon, D. E. Heppner, E. M. Johnston, J. W. Ginsbach, J. Cirera, M. Qayyum, M. T. Kieber-Emmons, C. H. Kjaergaard, R. G. Hadt, L. Tian, Chem. Rev. 2014, 114, 3659-3853. http://dx.doi.org/10.1021/cr400327t 
11. G. F. Swiegers, T. J. Malefetse, Chem. Rev. 2000, 100, 3483-3537. http://dx.doi.org/10.1021/cr990110s

12. B. Hasenknopf, J.-M. Lehn, N. Boumediene, A. DupontGervais, A. Van Dorsselaer, B. Kneisel, D. Fenske, J. Am. Chem. Soc. 1997, 119, 10956-10962. http://dx.doi.org/10.1021/ja971204r

13. M. C. T. Fyfe, J. F. Stoddart, Acc. Chem. Res. 1997, 30, 393 401. http://dx.doi.org/10.1021/ar950199y

14. T. R. Cook, Y.-R. Zheng, P. J. Stang, Chem. Rev. 2013, 113, 734-777. http://dx.doi.org/10.1021/cr3002824

15. J. Qin, F.-X. Li, L. Xue, N. Lei, Q.-L. Ren, D.-Y. Wang, H.L. Zhu, Acta Chim. Slov. 2014, 61, 170-176.

16. T. C. Stamatatos, G. Christou, Inorg. Chem. 2009, 48, 33083322. http://dx.doi.org/10.1021/ic801217j

17. G. Suss-Fink, Dalton Trans. 2010, 39, 1673-1688. http://dx.doi.org/10.1039/B916860P

18. M. Mehring, Coord. Chem. Rev. 2007, 251, 974-1006. http://dx.doi.org/10.1016/j.ccr.2006.06.005

19. J. K. Brask, T. Chivers, Angew. Chem. Int. Ed. 2001, 40, 3960-3976.

http://dx.doi.org/10.1002/1521-3773(20011105)40:21 <3960::AID-ANIE3960>3.0.CO;2-U

20. E. J. L. McInnes, S. Piligkos, G. A. Timco, R. E. P. Winpenny, Coord. Chem. Rev. 2005, 249, 2577-2590. http://dx.doi.org/10.1016/j.ccr.2005.02.003

21. L. Wang, J. Wang, C. Xie, J. Coord. Chem. 2008, 61, 34013409. http://dx.doi.org/10.1080/00958970802051058

22. Z.-G. Gu, Y.-F. Xu, X.-J. Yin, X.-H. Zhou, J.-L. Zuo, X.-Z. You, Dalton Trans. 2008, 41, 5593-5602. http://dx.doi.org/10.1039/b806619a

23. F. Escarti, C. Miranda, L. Lamarque, J. Latorre, E. GarciaEspana, M. Kumar, V. J. Aran, P. Navarro, Chem. Commun. 2002, 9, 936-937. http://dx.doi.org/10.1039/b110409h

24. J. A. Bertrand, J. A. Kelly, J. Am. Chem. Soc. 1966, 88, 4746-4747. http://dx.doi.org/10.1021/ja00972a053

25. Y. Li, L. Jin, J. Clust. Sci. 2011, 22, 41-47.

26. R. Vafazadeh, N. Hasanzade, M. M. Heidari, A. C. Willis, Acta Chim. Slov. 2015, 62, 122-129. http://dx.doi.org/10.17344/acsi.2014.797

27. J.-P. Zhang, Y.-Y. Lin, X.-C. Huang, X.-M. Chen, J. Am. Chem. Soc. 2005, 127, 5495-5506. http://dx.doi.org/10.1021/ja042222t

28. Z. Otwinowski, W. Minor. Methods in Enzymology, Vol. 276, edited by C. W. Carter Jr \& R. M.W. Sweet,. New York: Academic Press, 1997, 307-326.
29. A. Altomare, G. Cascarano, G. Giacovazzo, A. Guagliardi, M. C. Burla, G. Polidori, M. Camalli, J. Appl. Cryst. 1994, 27, 435-436.

30. P. W. Betteridge, J. R. Carruthers, R. I. Cooper, K. Prout, D. J. Watkin, J. Appl. Cryst. 2003, 36, 1487-1487. http://dx.doi.org/10.1107/S0021889803021800

31. S. Safaei, I. Mohammadpoor-Baltork, A. R. Khosropour, M. Moghadam, S. Tangestaninejad, V. Mirkhani, R. Kia, RSC Adv. 2012, 2, 5610-5616.

32. Z. K. Jacimovic, V. M. Leovac, Z. D. Tomic, Z. Krist-New Cryst. Struc. 2007, 222, 246-248.

33. R. T. Stibrany, J. A. Potenza, CCDC 666757: Private communication to the Cambridge Structure Database, 2007, doi: $10.5517 /$ ccqct95.

34. F.-F. Jian, P.-S. Zhao, H.-X. Wang, L.-D. Lu, Bull. Korean Chem. Soc. 2004, 25, 673-675. http://dx.doi.org/10.5012/bkcs.2004.25.5.673

35. G. Ondrejovič, A. Broškovičova, A. Kotočova, Chem. Papers 2000, 54, 6-11.

36. G. Ondrejovič, A. Kotočova, Chem. Papers 2006, 60, 10-21.

37. F. S. Keij, J. G. Haasnoot, A. J. Oosterling, J. Reedijk, C. J. O'Connor, J. H. Zhang, A. L. Spek, Inorg. Chim. Acta 1991, 181, 185-193. http://dx.doi.org/10.1016/S0020-1693(00)86809-7

38. A. W. Addison, N. Rao, J. Reedijk, J. V. Rijn, G. C. Verschoor, J. Chem. Soc. Dalton Trans. 1984, 1349-1356. http://dx.doi.org/10.1039/dt9840001349

39. Y.-H. Wen, X.-L. Xie, L. Wang, J. Coord. Chem. 2011, 64, 459-472. http://dx.doi.org/10.1080/00958972.2010.548862

40. R. Balamurugan, M. Palaniandavar, R. S. Gopalan, Inorg. Chem. 40, 2001, 2246-2255. http://dx.doi.org/10.1021/ic0003372

41. H. Nagao, N. Komeda, M. Mukaida, M. Suzuki, K. Tanaka, Inorg. Chem. 1996, 35, 6809-6815. http://dx.doi.org/10.1021/ic960303n

42. M. A. El-Sayed, A. H. Abdel Salam, H. A. Abo-El-Dahab, H. M. Refaat, A. El-Dissouky, J. Coord. Chem. 2009, 62, 10151024. http://dx.doi.org/10.1080/00958970802353652

43. M. A. El-Sayed, H. A. El-Wakil, T. S. Kassem, H. A. Abo-Eldahab, A. E. El-Kholy, Inorg. Chim. Acta 2006, 359, 43044310. http://dx.doi.org/10.1016/j.ica.2006.04.048

44. M. A. El-Sayed, T. S. Kassem, H. A. Abo-Eldahab, A. E. ElKholy, Inorg. Chim. Acta 2005, 358, 22-28. http://dx.doi.org/10.1016/j.ica.2004.08.025 


\section{Povzetek}

Sintetizirali smo dva bakrova(II) klastra $\mathrm{Cu}_{4} \mathrm{OCl}_{6}(\text { pirazol })_{4}$ (1) in $\mathrm{Cu}_{4} \mathrm{OBr}_{6}(\mathrm{Br} \text {-pirazol) })_{4}(\mathbf{2}) \mathrm{z}$ reakcijo acetilacetona z benzohidrazidom (razmerje 1:1) in $\mathrm{CuX}_{2}(\mathrm{X}=\mathrm{Cl}(\mathbf{1})$ in $\mathrm{X}=\mathrm{Br}(\mathbf{2})$ ) v metanolu. Strukturi obeh klastrov sta bili določeni $\mathrm{z}$ rentgensko difrakcijo. Klastra sta zgrajena iz štirih $\mathrm{Cu}$, enega $\mathrm{O}$, šestih $\mu_{2}-\mathrm{X}$ atomov in štirih pirazolskih ligandov. Pirazol je bil pripravljen in situ $\mathrm{z}$ reakcijo acetilacetona $\mathrm{z}$ benzohidrazidom v metanolu pri refluksu. V 2 se je metinski vodik na pirazolu substituiral z bromovim atomom. Štirje bakrovi atomi obdajajo centralni $\mathrm{O}$ atom v tetraedrični razporeditvi. Vsi bakrovi atomi so pentakoordinirani in imajo podobno koordinacijsko razporeditev ligandov v obliki nekoliko popačene trigonalne bipiramidalne geometrije. Ciklični voltamogram klastrov $\mathbf{1}$ in $\mathbf{2}$ kaže enoelektronski kvazi-reverzibilen redukcijski signal v območju 0,485 do 0,731 V ter enoelektronski kvazi-reverzibilen oksidacijski signal v območju 0,767 do 0,898 V. Pri 1 je opaziti tudi en ireverzibilen oksidacijski signal na pozitivni strani voltamograma pri $1,512 \mathrm{~V}$, ki bi ga lahko pripisali oksidaciji $\mathrm{Cu}(\mathrm{II})$ do $\mathrm{Cu}(\mathrm{III})$. 